reached at which radioisotopes could be regarded as true and tried tools and that industry would gain great benefit from their widespread adoption. He expressed the hope that all those interested in the production and use of isotopes would take the opportunity of visiting the Bureau, where the Authority was putting radioisotopes in the 'shop window'. Sir Hugh Beaver, acting president of the Federation of British Industries, commended the Authority on the excellent work it had done on research and development into isotope uses, and expressed the hope that industry would come forward and make use of the facilities which the Authority could make available in the form of advice and consultancy. The Bureau, which is open to the general public, is to be staffed by scientific personnel from the Authority's Radiochemical Centre at Amersham, who will be able to give on-the-spot advice to industrialists, doctors and research workers. Radioisotopes, the trade in which already amounts to nearly a million pounds, are widely used in industry, medicine, agriculture and research in the United Kingdom, and the Authority's Radiochemical Centre at Amersham supplies isotopes to more than sixty countries in all five continents. Sir Roger remarked that the use of radioisotopes by British industry could easily be increased tenfold.

International Co-operation and the Production of Calcium-47

Following a meeting of experts on the production of calcium-47 convened by the International Atomic Energy Agency in Vienna in December 1958, there have been successful efforts to produce this very useful radioisotope in Great Britain and the United States. Agency research contracts have so far been awarded to institutions in France and Sweden to promote research on production as well as practical applications of Ca-47. As reporter at a second meeting held in December 1959 in Vienna, limited amounts of this isotope are now available from Amersham and Oak Ridge. Although the present $\mathrm{Ca}-45$ contanination would not permit the use of this product for experiments on normal healthy persons, it is considered satisfactory for diagnostic and research work in patients and for agricultural and other applications. Tho International Atomic Energy Ageney is now developing a programme to assist, through research contracts, users of this isotope to procure it and to co-ordinate further work on applications of $\mathrm{Ca}-47$ as well as its production by methods other than the calcium-46 $(n \gamma)$ - calcium-47 reaction.

\section{Addiction-producing Drugs}

IN its tenth report, the Cormmittee on Addictionproducing Drugs which was set up by the World Health Organization recommends that eight new substances derived from different chemical groups and all having morphine-like effects should be subject to international control (Technical Report Series, No. 188. Pp. 16. Geneva : World Health Organization; London: H.M. Stationery Office, 1960. 1 Swiss franc; $18.9 d . ; 0.30$ dollar). These substances are allylprodine, benzethidine, furethidine, lævophenacylmorphan, metazodine, norlævorphanol, phenazocine and piminodine. The Committer feels that the fundamental criterion for the establishment and degree of control is the extent to which druginduced behavioural disturbences are a risk to the cormmunity, for neither the chemical structure per se nor any definition, however descriptive, can be a complete guide indicating which substances should be placed under control. Consequently, there is a need for research along various lines in the field of drug-addiction. In particular, to help the World Health Organization in carrying out its functions, the Committee must have at its disposal the results of basic and applied research in this field. So far, insufficient support has been fortheoming for such investigations. The Committee strongly urges that research on drug addiction should be strengthened and expanded, since it continues to be a serious international health problem. The Committee makes certain technical comments concerning the draft of the Single Convention on Narcotic Drugs. It expresses the view, inter alia, that only those preparations should be retained as exempted preparations which constitute no risk to public health, and from which the potentially addicting agent is not readily recoverable.

\section{Mud Fauna of the Stour Estuary}

ONE of the most striking features of any estuary is the replacement of freshwater animals by marine animals as the river progresses towards the sea. In spite of the presence of numerous estuaries in the British Islos, surprisingly few accounts of their ecology have been published. A study of tho River Stour estuary was made by Frances Bull, Helen Honeyman and Susan Knott over a period of three weeks during June 1958 (Transactions of the Suffolk Naturalists' Society, including the Proceedings of the year 1959. Vol. XI, Part III. Pp. 217-288. Ipswich: Miss Janet C. N. Willis, Honorary Secretary, 1 Holly Road, 1960. $7 s .6 d$.$) . The scope of the investigation$ was limited to burrowing animals and to their distribution in relation to salinity, substrate, and their level on the shore. Although no hard and fast lines can be drawn, the fauna of the estuary roughly falls into three groups, dopending on where each species attains a maximum density. It can be inferred that a maximum density implies optimal conditions for the life of the species. There are those species which. havo their maximum density in the upper reaches of the estuary, although they may occur in limited numbers right down to Shotley. Examples of this group are Corophium volutator, Nereis diversicolor and Streblospio shrubsolii. At the other end of the scale are those species which do not penetrate to the top of the estuary and have a maximum density towards the seaward end. These, for example Cardium edule and Nephthys hombergii, are generally marine species which have managed to penetrate the estuary. Although they can live in waters of lower salinity than the sea, they appear to be unable to survive the wide fluctuations of the upper reaches. Finally, there are those species with a mid-estuarine maximum, for example Hetercirrus sp., Scoloplos armiger and priapulos caudatus. A striking feature of the distribution of animals in the estuary is that, as soon as salinities becomo constant between high and low water, and the overall salinity higher, the total number of animal species rises, although the maximum density of any one is usually lowered. At Buck's Horns a total of 866 Corophium volutator and 720 Nereis diversicolor were collected from four stations, while an odd Scrobucularia plana and Cyathura carinata were the only other species present. The other extreme is shown by the transect at Shotley, where eighteen different species were found ; the maximum number of any one species collected was 137 Scrobucularia plana from six stations. 